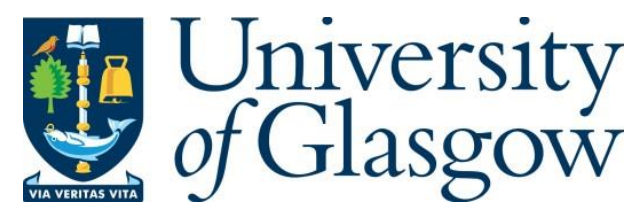

Gill, C. (2018) What can government agencies learn from the ombudsman? In: Hertogh, M. and Kirkham, R. (eds.) Research Handbook on the Ombudsman. Series: Research handbook in law and politics. Edward Elgar: Cheltenham, UK ; Northampton,

Massachusetts, USA, pp. 298-318. ISBN 9781786431240

(doi:10.4337/9781786431257.00026).

There may be differences between this version and the published version. You are advised to consult the publisher's version if you wish to cite from it.

http://eprints.gla.ac.uk/174091/

Deposited on: 26 November 2018

Enlighten - Research publications by members of the University of Glasgow http://eprints.gla.ac.uk 


\section{What Can Government Learn from the Ombudsman?}

\section{Chris Gill}

\section{INTRODUCTION}

This chapter examines whether and how government can learn from the ombudsman.

Ombudsman schemes frequently claim that their work has an impact on government and some scholars have been enthusiastic about the potential contribution of the ombudsman in this regard. However, there remains significant controversy over the extent to which the ombudsman should be helping government to learn. Pragmatically, it seems self-evident that errors picked up by the ombudsman in the course of investigations should not be allowed to recur. Matters become contested, however, where the ombudsman takes on a more proactive role and seeks actively to influence government, through mechanisms including systemic investigations, providing guidance, giving advice, and delivering training. Indeed, where an ombudsman becomes more directive in seeking to influence government, questions of constitutional propriety arise around checks and balances on the ombudsman's activities. There is a concern here that, by taking on a more directive and managerial role within the administrative process, the ombudsman may be usurping the proper role of government administrators. A starting point for discussing the ombudsman's role in relation to helping government learn, therefore, is to recognize that the role is contested and that its proper limits remain a matter for debate.

It is probably uncontroversial to accept that the ombudsman has at least some role in promoting governmental learning (however limited and delineated). Indeed, ombudsman scholarship has been dominated by discussion of the potential for the ombudsman to fulfill a more dynamic role in relation to government, whether that is characterized as 'fire-watching' (Harlow and Rawlings 2009), 'fire-prevention' (Abrahams 2012), or 'control' (Heede 2000). In this regard, scholars have identified a number of assets and liabilities that the ombudsman institution possesses in relation to generating learning within government. Assets include strong powers of investigation, the ability to make recommendations, and the ability to consider aspects of the administrative process untouched by the courts. Liabilities include questions over whether pragmatism trumps principle in ombudsman decisions, whether modern complaints management techniques lead to a loss of learning, and whether the closeness to government required to help it learn may lead to a form of regulatory capture. The question of the ombudsman's theoretical potential to help government learn is complicated, of course, by the fact that assets and liabilities vary significantly between ombudsman schemes and between national jurisdictions. The fabulous variety of the ombudsman institution around the world, and its ability to be grafted into vastly different legal and political systems, is considered to be part of the genius of the institution Reif 2004). However, this makes generalization on a global scale all but impossible. ${ }^{1}$

There is also significant variation in the aspects of government overseen by the ombudsman. Some ombudsman schemes oversee local government, others central government,

\footnotetext{
${ }^{1}$ For this reason, this chapter - while seeking to bring out some of the inherent, cross-cutting difficulties in assessing the ombudsman's learning role - does not attempt to provide a holistic overview, applicable across the world. Instead, the literature reviewed and the predominant focus of the chapter is on the ombudsman institution as it operates in Western states.
} 
while some consider specialized agencies such as the military or the police. The scope of ombudsman schemes also differs, with some having a maladministration focus, some considering human rights, some having criminal anti-corruption powers, and others still taking on functions as auditors, inspectors, and regulators. When one also considers the varying ways in which government is administered across the world, we are faced with an almost infinitely variable set of combinations: different ombudsman schemes overseeing different administrative settings in different jurisdictions. More generally, considering the nature of government administration is a matter which has often been overlooked in debates about whether the ombudsman either should or can help government to learn. These discussions have had a 'topdown' emphasis on the perceived qualities of the ombudsman institution and have often had very little regard for the realities of the government bureaucracies which the ombudsman oversees. Indeed, whether government learns is as much, if not more, a matter of how government functions as it is a matter of the particular approach, powers, and functions of the ombudsman. Here, the literature in the fields of public administration and organizational science has tended to be pessimistic with regard to the potential for achieving learning and directed change in government.

This chapter explores these issues and is structured in five parts. Firstly, it will consider literature examining the significant challenges around controlling government action, drawing on scholarship concerned with bureaucratic control, policy implementation, decision-making, and organizational learning. Secondly, the chapter will consider normative arguments around the ombudsman's role and the debate around how far the ombudsman should be involved in helping government learn. Thirdly, the theoretical assets and liabilities of the ombudsman in terms of whether it can help government learn will be examined. Fourthly, the chapter will present two case studies, showing contrasting approaches which ombudsman schemes have taken to assisting governmental learning. Finally, the chapter will turn to examine the limited empirical studies that have investigated bureaucratic responses to the ombudsman and consider the challenges around improving our empirical understanding in this area.

\section{LEARNING WITHIN GOVERNEMNT ORGANIZATIONS: REASONS TO BE SKEPTICAL}

Accountability mechanisms, such as the ombudsman, have been seen to fulfil three goals: a democratic goal (checking that the will of political principals is done); a constitutional goal (uncovering and fixing abuses of power); and a learning goal (promoting improvement in government) (Bovens et al 2008). While the first two goals have traditionally been at the heart of the mission of accountability mechanisms, there has been increasing emphasis on harnessing the work of accountability mechanisms to help government learn (Aucoin and Heintzman 2000). The growth in importance of learning and improvement has partly been driven by the New Public Management (NPM) reforms that have been a hallmark of most Western democratic states over the past thirty years (Hood and Dixon 2015). This has involved, amongst other things, a disaggregation of the policy making and policy delivery functions of government, with problems of imperfect control compensated for in part by the expansion of internal accountability mechanisms within government (Hood et al 2000). Importantly, the NPM reforms emphasized a particularly instrumental view of accountability mechanisms, where improved managerial performance and an emphasis on improving the quality of bureaucratic outputs came 
to be seen as increasingly important. It is perhaps not surprising, in this context, that scholars have noticed an increasing trend towards the ombudsman seeking to influence government action and help it to learn (Buck et al 2011).

However, concurrently with this developing emphasis on learning as a goal of accountability, a substantial literature has developed in the fields of public administration and organisational science, which suggests that achieving directed change in government is a particularly challenging task. Some of the earliest studies of policy implementation, for example, highlighted multiple barriers to policymakers making their policies a reality and these findings have tended to be confirmed in study after study in the last half century, to the extent that studies of implementation have been dubbed 'misery research' (Pressman and Wildavsky 1973; Rothstein 1998). A particular focus of so called 'bottom up' implementation research has been on investigating the influence of frontline bureaucrats, who are seen as resistant to control and hugely powerful actors in terms of the policy implementation process (Alden 2015). These bureaucrats have been portrayed as shaping the reality of policy on the ground, with David Lipsky famously concluding that: "The decisions of street-level bureaucrats, the routines they establish and the devices they invent to cope with uncertainties and work pressures, effectively become the public policies they carry out.' (1980, xii)

The difficulty of controlling bureaucratic actors has also been studied in literature concerned with the control of government, which is centrally informed by principal agent theory. This theory examines the implications of delegated authority, where the principal is seen as entering into a contract with an agent, who is entrusted to carry out the specified wishes of the principal (Gormley and Balla 2004). Principal-agent theory identifies two problems wherever power is delegated: it is difficult, ahead of time, to know whether the agent entrusted with a task has the capacity to perform it (adverse selection); and it can be very difficult to monitor subsequently how the agent is performing in practice (moral hazard). Any delegation is seen to involve 'agency loss' where the capacity of the principal to achieve their goals is limited by adverse selection and moral hazard (ibid.). The literature on the control of government tends to counsel realism in relation to the extent that bureaucratic agents can be controlled by their principals, whether these are external or internal to the organisation (Hood 1995; Beck Jorgensen and Vranbaek 2011). Systems of control are seen as imperfect, because they do not have the requisite variety to match the complexity of modern bureaucratic systems. Principals who seek control over their bureaucratic agents require clear directions, an effective method of detecting error, and an effective means of correcting error. However, because any system of control is only as good as its weakest element and since principals are often ambiguous in their directions, have insufficient data about what is happening in government administration, and are restricted in their abilities to coerce other actors, there are serious limitations on the achievement of bureaucratic control (Dunsire 1992).

Other literature which is relevant to the discussion here includes empirical work which has sought to explore the extent to which courts control bureaucratic action (Hertogh and Halliday 2004). These studies have generally found that the courts struggle to assert their values within the 'administrative soup' of rival influences (Sunkin 2004). Other literature concerned with analysing fairness in bureaucratic decision-making also suggests that bureaucracies are highly competitive normative environments, in which rival conceptions of fairness struggle for dominance (Mashaw 1983; Adler 2010). Here the extent to which government decision-making can be made subject to external control has been treated with significant scepticism, with some concluding that the 'natural hegemony' of bureaucratic approaches tends to edge out ideas of 
individual fair treatment (Galligan 1996). This echoes work on NPM, which identifies three key types of bureaucratic values: sigma values ('keep it lean and purposeful'), theta values ('keep it honest and fair') and lambda values ('keep it robust and resilient') (Hood 1991). NPM's concern with frugality and efficiency means that bureaucracies have increasingly tended to shift towards the adoption of sigma type values. The extent to which internal or external mechanisms of control and accountability are likely to be effective, therefore, is at least partly down to the normative characters of the bureaucratic environment in question. Indeed, a conclusion from this chapter so far is that the characteristics of the system subject to control are likely to be as important as the characteristics of the mechanisms seeking to exercise control.

Our concern in this chapter, however, is not simply on whether mechanisms of accountability are able to exert control, but on whether they are able to bring about learning in government. This is a broader notion, which calls for a 'bottom up' perspective on the organisational processes through which people in organisations respond to experience (from both internal and external sources) and change their cognition and behaviour (Argyris and Schon 1978). The primary conclusion of literature in the field of organisational learning is that organisations tend to be ineffective at learning, with long lists of barriers to effective learning including issues around capacity, organisational commitment, and resources. Indeed, organisations tend not only to be bad at learning, but actually create routines which are designed to avoid the feelings of vulnerability associated with learning: 'Organisations deliberately create self-reinforcing, anti-learning processes to overprotect the actors to make sure that they are protected from difficult and embarrassing problems. Such routines are eventually taken for granted.' (ibid., 7).

These pathologies of anti-learning are likely to be exacerbated in the context of government organisations (Common 2004; Thomas 2015). These problems include election cycles which can disrupt learning continuity, poor quality legislation, and a blame environment which discourages risk taking (Gilson et al 2009). In the public sector context, NPM reforms have severely limited the capacity of organisations not only to learn in the first place, but to remember what they have learnt (Pollitt 2009). A common suggestion in this literature is that government organisations tend to be incapable of 'double-loop' learning (where fundamental values, approaches, and processes are re-evaluated) and instead, where learning occurs, it tends to be 'single loop' (where the focus is on making existing processes work more efficiently, without challenging the basic values underlying them) (Argyris and Schon 1978; Thomas 2015). This is seen as a problematic, since many challenges faced by government are 'double-loop' in nature, yet are dealt with in a short-term, problem-solving, 'single loop' fashion (Leeuw and Sonnichsen 1994). Where the learning stimulus comes from outwith the organisation, learning has also been thought to involve particular challenges since organisational boundaries can be hard to penetrate, with some suggesting a natural tendency for organisations to become unresponsive to their external environments (Von Acker et al 2015). Here, organisations tend only to respond with positive learning routines where external stimuli are consistent with their existing frames of reference; where they are not, the chances of them permeating organisational boundaries are reduced.

In summary, therefore, the literature surveyed above suggests that the starting point for considering the role of the ombudsman in helping government to learn is to be sanguine about the significant challenges inherent in bringing about learning and directed change in complex bureaucracies. This starting point is seen as an important corrective to existing literature on the ombudsman, which has tended to focus mainly on the theoretical characteristics of the 
ombudsman rather than the reality of the bureaucratic organisations they oversee. Having set out this baseline, the chapter now turns to examine literature specifically concerned with the ombudsman's role in helping government to learn.

\section{SHOULD THE OMBUDSMAN HELP GOVERNMENT TO LEARN: A CONTESTED ROLE}

Before one can evaluate the success of the ombudsman institution, one must understand its core purpose and functions (Seneviratne 2002). However, a recurring theme in ombudsman scholarship has been to question what the ombudsman should be doing. Much of this debate has been concerned with normative arguments around whether the ombudsman should be concerned primarily with righting individual injustice (redress) or with proactively seeking to bring about bureaucratic improvement (control) (Heede 2000)? A number of other metaphors have been used to characterise these different roles, including 'fire-fighting', 'fire-watching' and 'firepreventing' (see Harlow and Rawlings 2009; Abrahams 2012). Proponents of the control approach argue that key features of the ombudsman - its inquisitorial approach, its concern with the quality of the administrative process, its ability to make and follow up recommendations make it well suited to helping bureaucrats learn (Harlow 1978; Lewis and Birkinshaw 1993). In this view, an excessive focus on individual complaints turns the ombudsman into a small claims court, with a limited and consumerist focus on redress rather than a broader role in relation to facilitating deliberative democracy and citizen participation in the processes of government (O'Brien 2015). Here, the specific contribution of the ombudsman to the administrative justice system is its ability to audit administrative processes and bring about systemic change (Harlow 1978). Concern has been expressed, however, that if the ombudsman lays too much emphasis on ex ante measures to improve and control public administration, this will lead to a loss of focus on the individual citizen (Stuhmcke 2012). There is also concern that techniques associated with the 'fire-watching' approach - such as investigations launched at an ombudsman's own initiative rather than following a complaint - can reduce the legitimacy of the ombudsman and risks politicizing the institution. Nonetheless, a key trend in the literature has been to suggest that ombudsman schemes are increasingly prioritizing fire-watching approaches, although different ombudsman schemes continue take different approaches, ranging from 'reactive' to 'proactive' (ibid.).

The proper role of the ombudsman is also a matter of constitutional importance, since the 'fire-fighting' and 'fire-watching' approaches each have different implications in relation to the constitutional positioning of the ombudsman and their relationships with other state actors. An aggressively fire-watching approach, for example, where individual complaints are used largely as intelligence for launching large scale systemic audits of administrative practice, might be seen to overlap with the functions of existing scrutiny bodies such as auditors and inspectors. It might also lead to a change in emphasis on protecting the individual citizen and providing a route for the individual's voice to reach the ears of those in power (Stuhmcke 2010). On the other hand, a reactive approach overly focused on fire-fighting and the provision of individual redress might be seen to duplicate the work of other redress mechanisms such as courts and tribunals and to fail to make a clear additional contribution to the administrative justice system.

Indeed, while there is widespread agreement that ombudsman schemes have become a valuable part of the constitution, the notion of the ombudsman as a 'constitutional misfit' retains 
some purchase (Snell 2000). Scholars have traditionally emphasised the parliamentary role of the ombudsman, with it acting as an adjunct of parliament and a support to the legislature's scrutiny of government action (Giddings 2008). Here ombudsman schemes have been categorised as: '...as auxiliary mechanisms to aid political principals to oversee their administrative agents.' (Von Acker et al 2015, p. 40)

Others have seen the ombudsman as performing a more hybrid function, stressing not only its relationship to parliament but seeing it as a supplement to traditional administrative law remedies available in courts and tribunals (Maggette 2003). In this view, the ombudsman spans political and legal forms of redress. A third view, influenced by developments in Australia, has argued that the ombudsman should be seen as part of a developing branch of government styled as the 'integrity branch' which includes auditors, regulators, inspectors and other bodies concerned with probity in public administration (Buck et al 2011). Thus, the argument here is that the debate over the role of the ombudsman needs to be considered not only in terms of whether they are suited to task of helping government learn, but also in terms of how such a role aligns with the constitutional position of the ombudsman. The question is a fundamental one with regard to the constitutional source of the ombudsman's legitimacy. Recent developments in Australia and Scotland have, for example, raised concerns that ombudsman schemes have been given additional functions (in relation to audit and the regulation of complaint handling) which have the potential to cloud their impartiality and blur the boundary between the ombudsman and the executive (Gill 2014). Indeed, in suggesting that the ombudsman should have a stronger role in shaping administrative action and in helping one of the parties to improve, there is a danger that the ombudsman might put its impartiality at risk.

Several important points arise from this discussion. The first is that the legitimacy of the ombudsman's attempts to influence bureaucratic practice is contested. There are good arguments for the ombudsman to concentrate on providing redress for individual citizens and some potentially troubling constitutional implications in relation to the ombudsman proactively helping government to learn. The second point arises from the first: if there is a question mark over the constitutional propriety of the ombudsman's attempts to influence bureaucratic practice then this may limit its effectiveness in doing so. An absence of clarity around the ombudsman's roles and the constitutional legitimacy of its actions may hinder any attempts to ensure that learning occurs as a result of its work by increasing bureaucratic resistance. The third point is that there is a significant spectrum amongst ombudsman schemes in relation to how they interpret their roles and whether they prioritize redress or control. Some take a more reactive stance while others are more proactive - as a result, the extent to which we may expect learning to take place is likely to vary significantly depending on how ombudsman schemes see their core function. More generally, this discussion highlights the importance of approaching the empirical question of whether government learns from the ombudsman with a clear understanding of the uncertainty and variability of the ombudsman's role. While few would argue that ombudsman schemes should have no role in relation to helping government to learn, there is significant debate about the way in which this role should be delineated and the extent to which it should be prioritized.

\section{CAN THE OMBUDSMAN HELP GOVERNMENT TO LEARN: THEORETICAL ASSETS AND LIABILITIES}


Having considered the normative issues surrounding the ombudsman's learning role, this section reviews the theoretical arguments about whether the ombudsman is in a position to help government to learn. Can the ombudsman fulfill such a role? The ombudsman has both assets and liabilities in this regard and these are summarized in the table below. ${ }^{2}$

\section{[INSERT TABLE 1 HERE]}

\section{Figure 18.1: potential assets and liabilities in relation to the ombudsman's learning role}

Beginning with the ombudsman's institutional assets, ombudsman scholars have generally been fairly positive about the potential for the ombudsman to influence bureaucratic action. Kirkham (2006), for example, highlights the inquisitorial approach of ombudsman schemes as facilitating the kind of intense scrutiny likely to lead to administrative improvement. The ombudsman's ability to make recommendations is considered as a strength of the institution (Gregory and Drewry 1991). These powers distinguish the ombudsman from the adversarial and reactive approach of the courts and give the institution much more scope to examine the administrative process and to identify areas for improvement (Seneviratne 2002). Other aspects of the ombudsman's procedural approach, such as its ability to develop close and collaborative relationships with administrators and to enter policy networks, are often cited as strengths (Van de Pol 2009). The fact that the ombudsman is able to build relationships, and enter into continuous dialogue, with the bodies it investigates has been argued to provide a strong basis for the receipt of guidance and advice by administrators (Farrand 1999). This is particularly the case for local ombudsman schemes, which are able to develop more direct and personal relationships with administrators (Van de Pol 2009). Indeed, the ability of the ombudsman to act both as an adjudicator and as an influential policy actor is seen as a potential strength of the institution, which makes it better suited for dealing with the complex polycentric problems of resource allocation which are often at the heart of citizens' grievances (King 2012).

The nature of the ombudsman's jurisdiction has also been perceived as a strength in relation to helping officials to learn. Indeed, it is clear that the concept of maladministration allows ombudsman schemes to go much further in probing bureaucratic action than does the legal conception of good administration (Steyvers and Reynart 2009). That ombudsman schemes are able to consider a broader range of bureaucratic behaviour is, therefore, considered as potentially enhancing their ability to identify problems since they are able to look at a wide range of administrative matters. The ability to publish annual reports and issue guidance is also cited as an advantage in relation to shaping future bureaucratic action (ibid.). Indeed, the development in the UK of principles of good administration has been noted as a major development in relation to providing guidance to administrators (Kirkham 2007). Own initiative powers of investigation where an investigation can be launched without receipt of a complaint - are suggested as particularly helpful in relation to identifying areas of weakness where government requires to improve (Buck et al 2011). The use of publicity and the media as a tool to help secure compliance and provide a complement to the ombudsman's moral authority, are considered to be effective in relation to ensuring that government accepts recommendations (O'Reilly 2009). More generally, some ombudsman schemes have argued that their very existence exerts an influence on administrative practice which, although it cannot be measured, should be not ignored. One former ombudsman referred to this as a 'tonic effect' (Compton 1970).

\footnotetext{
2 The terms assets and liabilities are borrowed from Steyvers and Reynart (2009).
} 
A number of liabilities have, however, been suggested in relation to the extent to which the ombudsman can fulfil a role in helping government learn. One issue is the increasing trend for ombudsman schemes to use informal resolution methods rather than the 'Rolls Royce' administrative audit style investigations that used to characterise the institution (Bondy et al 2014). The key idea behind 'modern complaints management' is that quick resolutions to complaints are proposed without finding out what went wrong or why (Cabinet Office 2000). From a learning perspective, the risk is clearly that a focus on individual satisfaction and a superficial treatment of cases militates against the intense scrutiny of processes provided by more formal investigations. This will also tend to reinforce a problem-solving or single-loop approach, where only presenting issues are addressed at the expense of more fundamental change. Indeed, Kirkham (2005) has noted that some have criticised the 'local settlement' process used by some ombudsman schemes because it could be used by organisations to shield themselves from more probing investigation.

A major limitation highlighted by those who consider that the ombudsman should primarily be a fire-watcher is the absence of own initiative powers of investigation in some schemes. As some have pointed out, ombudsman recommendations can often be dismissed by administrators on a 'damage score argument', where complaints are seen as representing a small sample of unrepresentative cases (Steyvers and Reynart 2009). More generally, while compliance with ombudsman decisions and recommendations generally appears to be good, it is not perfect. In the UK, some have noted with concern a tendency by government departments to push back on ombudsman recommendations (Kirkham et al 2008). Others have suggested that the ombudsman's reliance on the goodwill of those investigated is problematic, especially where there is an absence of parliamentary support for the office (Lewis and Birkinshaw 1993). While the idea that the ombudsman's closeness to, and good relationships with, administrators suggests that it will be able to exert influence over them more effectively, there is also a danger that this closeness will lead to the ombudsman becoming 'captured' by the bureaucrats it is meant to oversee (King 2012).

A further issue relates to the ombudsman's ability to develop coherent standards to guide the behaviour of public bodies. While the maladministration standard is broader than good administration in law, its exact meaning is 'notoriously uncertain' (Kirkham 2006). While the development of 'principles' (PHSO 2009) and 'axioms' (LGO 1993) of good administration is a step forward, there remains uncertainty about the extent to which pragmatism or principle predominate in the decision-making of ombudsman schemes (Gill et al 2013). Indeed, it has been noted that in their attempts to secure redress for individuals, ombudsman schemes often fudge matters of principle; this has been referred to as a matter of reaching a 'balanced accommodation' between principles of good administration and the realities of bureaucratic practice (Seneviratne 2002). Recent literature examining the development of 'ombudsnorms' has noted that published ombudsman decisions do not often refer to the standards being used and do not, therefore, demonstrate the connections that may be made between the particular facts of the case and the general principle that may be drawn from it (Remac 2013). There is, therefore, a question mark over what may be learned from the ombudsman in terms of substantive and transferable principle.

More pragmatically, some have questioned the effectiveness of external measures to improve bureaucratic practice and noted the potential for defensive behaviour rather than improvement on the part of bureaucrats as result of the ombudsman's work (Adler 2003). This has been a frequent charge levelled at accountability mechanisms and has been referred to as the 
accountability paradox, whereby accountability does not necessarily lead to improved performance (Bovens et al 2008). Others have talked of an accountability trap, where institutions get better at meeting the requirements of accountability mechanisms, while taking their eyes off improvements in service delivery (ibid.). The potential pathologies that may arise from bureaucratic responses to oversight include: tunnel vision, ritualization, mutual stereotyping, defensive routines, and hostile behavior (ibid.). Some have criticized the way accountability mechanisms lead to a loss of agency and moral judgment by organisational actors, undermining the development of learning and self-reflection (Jos and Tompkins 2004). The potential for defensive approaches in response to accountability mechanisms has been seen as especially prevalent where issues arise from individual experiences, where the evidence base for recommended actions and changes can be seen to lack legitimacy (Van de Pol 2009). Some administrative justice scholars have argued that - given the challenges of seeking to influence bureaucratic practice from the outside, the focus ought to be on internal improvement and learning processes as the best means of achieving better government decision-making (Adler 2003).

\section{CASE STUDIES: TWO CONTRASTING APPROACHES TO HELPING GOVERNMENT LEARN}

Having considered the normative and theoretical debates surrounding the ombudsman's learning role, this section presents two case studies which highlight contrasting approaches which ombudsman schemes are taking to helping government to learn. These serve to illustrate some of the issues discussed so far in this chapter.

\section{The Scottish Public Services Ombudsman - the ombudsman as quasi-regulator}

The Scottish Public Services Ombudsman has traditionally been seen as having a fire-fighting orientation (Thompson 2006). However, since the office was granted new powers to oversee the simplification and standardisation of public service complaints processes in 2010, the organisation has shifted to a much more proactive ombudsman model (Gill 2014). The ombudsman's new role includes:

- monitoring practice and identifying trends in complaint handling,

- promoting best practice in relation to such complaint handling,

- encouraging co-operation and the sharing of best practice among public bodies,

- publishing model complaint processes,

- issuing statements of non-compliance where a public body does not comply with a model complaint process.

These new functions have been described as a 'design authority' role (Scottish Government 2008). In practice, the SPSO has created a small internal unit within the organisation called the Complaints Standards Authority (CSA). The SPSO's latest annual report highlights the range of activities conducted by the CSA: the facilitation of professional complaint handling networks, the provision of training, the creation of e-learning modules on complaint handling, the development of collaborative monitoring arrangements with audit and regulatory bodies, and the development of standardised performance indicators. In relation to the latter, each model complaints process contains suggested performance indicators and requires the publication of 
complaints data. These indicators include: statistical information on complaints received and resolved at various stages of the process; a statement outlining improvements to services as a result of a complaint; and a measure to assess customer satisfaction with the complaints service provided. In addition, the SPSO has recently received additional project funding to set up a Learning and Improvement Unit (LIU), whose role is to work collaboratively with organisations subject to significant complaints in order to help them improve. The LIU was described in the SPSO's annual report as a significant development in the ombudsman's role: '...going beyond how complaints are handled to the heart of how authorities can use learning from them to bring about genuine and long-lasting change.'(SPSO 2016, 5).

This role involves providing advice and support to organisations generating high volumes of complaint to support improvement initiatives and assist with the implementation of recommendations.

As may be clear, the SPSO's new powers involve a significant increase in the work undertaken by the ombudsman outwith the investigation of complaints. While the latter remains the core business of the organisation and while the bulk of the ombudsman's staff remain involved in these activities, this has now been complemented by a range of quasi-regulatory activities such as standard setting and performance monitoring. The approach adopted by the SPSO emphasises collaboration with stakeholders and a key element of recent changes has been the convening of complaint handling networks, which are used to develop improved complaint handling practice. While the focus of the SPSO's improvement work to date has very much been on complaint handling (rather than substantive administration) (Gill 2012), there are now signs that its ambitions are growing with the creation of the LIU. The latter appears to involve a move beyond the quasi-regulatory approach of the CSA, towards a consultancy and advice model, which involves more prolonged engagement with particular organisations. While the SPSO has strongly advocated its model of ombudsmanry to other ombudsman schemes, the approach has remained low key and consensual in terms of how relationships with bodies under jurisdiction are managed. For example, the SPSO has to date made only limited use of thematic investigations and has not adopted particularly systemic approaches to casework investigation.

There have yet to be any formal evaluations of these recent developments, but the SPSO's approach highlights several of the potential assets and liabilities discussed above. Potential assets include the development of close, collaborative relationships with bodies under jurisdiction, using the ombudsman's ability to operate as a policy actor to influence administrative practice. A further asset relates to the increased focus on developing clear normative guidance for bureaucrats, setting authoritative standards around complaint handling. Potential liabilities in part arise from these potential assets: the closeness of the ombudsman to those under investigation may, in time, raise questions about the office's impartiality. A certain amount of constitutional blurring is also in evidence here, as the ombudsman begins to work as a consultant with poor performing authorities. It is presumably only a matter of time before the ombudsman is called upon to determine a complaint with regard to systems, policies, processes, or practices that have arisen following the provision of the LIU's consultancy and advice service. While this more interventionist approach is a strong potential asset in helping to prompt learning, there is a question over whether this managerial model oversteps the mark and usurps the proper functions of administrators.

\section{The Ontario Ombudsman - the ombudsman as systemic investigator}


The Ontario Ombudsman (OO) has developed an international reputation for its systemic investigation work. Their approach has its genesis in proposals to abolish the office and a perceived need identified by the ombudsman at the time to make a stronger and more obvious case for the value of the office (Marin 2009). As a result, the OO's office has sought consciously to differentiate itself from the traditional ombudsman role. Andre Marin, the former ombudsman, describes the traditional approach of ombudsman schemes to achieving change in government as involving shuttle diplomacy, informal networking, and annual reports (ibid.). This approach is described as a complaint resolution model, involving 'low-level intervention' and is seen as limited for five reasons: shuttle diplomacy relies on good faith on the part of bureaucrats; low level intervention is not suited to situations where parties are very litigious or disagree strongly on the facts; government priorities are seen as unlikely to change without a significant amount of pressure being brought to bear; working quietly in the background does not demonstrate the ombudsman's value to citizens; and a focus on informal resolution means that systemic and recurring issues are missed (ibid.). The shift in the OO's approach has involved moving away from what was described as deference and conflict avoidance, to one which is principled and seeks to bring issues of good governance firmly to the government's agenda (ibid.). This is described as moving the ombudsman from a complaint department to a service concerned with the 'architecture of governance' (ibid.)

The hallmarks of the OO's approach are: use of high profile media interventions; robust investigation techniques; and the pursuit of broader issues identified as having system wide relevance. One of the means through which these hallmarks have been delivered is through the creation of a Special Ombudsman Response Team (SORT) to conduct large scale inquiries involving face-to-face tape recorded interviews of bureaucrats and research into best practice in other jurisdictions (ibid.). Once investigations are complete, the ombudsman requires updates on implementation from government bodies, but also goes beyond this by re-investigating the issues to ensure that problems have been satisfactorily addressed (ibid.). At each stage of the investigation, the media is involved by the ombudsman's office. Press conferences are convened to launch investigations and to publicise outcomes and follow-ups (Jones 2009). Reports are given catchy titles, are written in an accessible format, and designed to be easily turned into copy by the mainstream press (Dube 2016). Recent examples of systemic investigation reports include Careless About Childcare, which contained 113 recommendations for the Ontario Ministry of Education and A Matter of Life and Death, which made 22 recommendations in relation to police de-escalation techniques (ibid.). In addition to its work in specific cases, the OO has sought to establish its approach as a model internationally, partly as a further means of establishing the 'added value' of the office. This has involved the publication of a book outlining the ombudsman's approach to investigation and an international ombudsman training programme aimed at popularising the OO's robust investigation style, called Sharpening Your Teeth (Jones 2009).

How does this approach compare with that of the SPSO? One clear difference is the significant emphasis on investigation as the principal means through which learning is achieved in government. In some ways this is a more traditional approach than that championed by the SPSO, with its use of standard setting and advice outwith cases. It is notable that the OO's training is solely aimed at other administrative watchdogs, while the SPSO's training unit involves the delivery of complaint investigation training to public bodies under its jurisdiction. This is suggestive of a very different emphasis, with the OO generally placing itself in a more adversarial position in relation to the bodies under its jurisdiction rather than one which provides 
direct support. This is also indicated through the OO's use of the media, with investigations played out in a very public fashion, whereas the SPSO's approach emphasises consensus building behind the scenes. Another clear difference in approach relates to how the offices position themselves in relation to citizens. The OO, in part, uses its robust and high profile approach in order to connect with citizens and make them feel that the office is there to represent them. The presentation of the office as 'Ontario's Watchdog' and the use of media-friendly language in reports is very much designed to bring citizens on board and provide the ombudsman with the public support required for cases where government's feathers will be ruffled. While stressing that such approaches actually enhance cooperation in the vast majority of low level cases (ibid.), it is quite different from the SPSO's approach, where work is conducted largely in private and few attempts are made to engage citizens at large with the work of the office.

What both approaches have in common is a clear will to influence government action in a very directive way. Where the SPSO's systemic work remains largely confined to improving complaint handling, however, the OO targets substantive administration much more clearly. It also seems evident form the OO's reports that their systemic focus often involves a first principles review of administrative action rather than a focus only on the quality of action assessed against existing policies and procedures. Indeed, their reports are often supported by extensive research into practices in other countries and are supported by expert testimony from independent specialists in the areas being investigated. This seems a broader emphasis on improvement and catalysing change than a more traditional one which is restricted to ensuring the fair treatment of individuals. For both the OO and the SPSO, the systemic role and the importance of the ombudsman's office are seen as an ability to shape the structures of government - the SPSO through its 'design authority' role and the Ontario Ombudsman through its perceived role enhancing the 'architecture of governance'.

In terms of assets and liabilities, a clear asset of the OO's approach is the principled approach it adopts, with investigations that are robust and which result in extensive directions for change. There seems to be little room in the OO's approach for pragmatic responses and fudges of principle. The quality of the systemic investigation process also seems high and although informal resolution techniques are used in low-level cases, the frequent and high profile systemic investigations provide a clear normative basis for the OO's work. By conducting investigations of significant depth and breadth, the OO seems willing to uncover and address 'double-loop' issues, rather than focus only on 'single loop' matters. The direct relationship with citizens which the $\mathrm{OO}$ achieves can be seen both as an asset and a liability. On the one hand, a call for popular support clearly reinforces the democratic mandate of the ombudsman as an institution which is there to ensure the fair treatment of the individual in the context of what are often unresponsive political and bureaucratic systems. On the other hand, the ombudsman has often been seen as deriving authority from its parliamentary connection and the idea of seeking a direct popular mandate is potentially controversial and could lead to the politicisation of the institution. This also points to a potential liability, shared with the SPSO, in relation to the usurpation of functions of other government actors - the dynamic approach of the ombudsman and the office's apparent willingness to tackle issues of political controversy in a very directive fashion is bound to lead to questions of legitimacy and constitutional overreach. There is also a question of effectiveness at stake here. While the OO believes strongly that its approach has changed government for the better, its more adversarial approach may well - in practice - alienate administrators and lead to shallow or defensive compliance, rather than a genuine commitment to change. This may militate against internalisation of norms and the development of better administrative judgment. 
A summary of the different approaches adopted by the SPSO and OO is presented in the table below.

\section{[INSERT TABLE 2 HERE]}

\section{Figure 18.2: contrasting approaches to the ombudsman's learning role}

This brief review of two different approaches to bringing about change in government demonstrates some of the difficulties in generalising about the ombudsman institution, particularly when the question is considered across jurisdictions. Different ombudsman schemes may take quite different approaches to their roles and in the absence of empirical evaluation of these approaches, it is difficult to say how effective these types of approaches are, beyond pointing out their theoretical assets and liabilities. Unfortunately, empirical evaluations have been few and far between and, where they have taken place, it is not always clear how much can be extrapolated from individual case studies.

\section{DOES THE OMBUDSMAN HELP GOVERNEMNT TO LEARN: THE LIMITED EMPIRICAL EVIDENCE}

The chapter now turns to a review of the limited empirical data which has been gathered on the ombudsman's learning role and, first, considers the methodological and conceptual challenges involved in empirically investigating this issue.

\section{Methodological and conceptual challenges}

Before examining the findings of empirical studies, it is important to consider the challenges that surround empirical research looking at the relationship between the ombudsman and government. ${ }^{3}$ Some of these challenges are conceptual. The way in which the phenomenon being investigated is presented, for example, varies significantly between studies; concepts used to describe the focus of studies include influence, impact, policy impact, control, improvement, transparency, learning, effects, and so on. Studies have also tried to evaluate different things: some have been concerned with measuring the attitude of administrators to the ombudsman, while others have sought to examine the impact of particular recommendations on policies and processes. Studies have not always been clear about the aspects of the ombudsman's work they are concerned with examining: the investigation process itself, the decisions and recommendations of the ombudsman, work outwith investigations such as training and policy work, etc. The nature of the changes examined in government also varies between studies: in most cases, this is restricted to considering whether changes have occurred, rather than in a subsequent evaluation of whether those changes could be described as improvements. There is also a tendency in studies not to differentiate clearly between the nature of changes being examined: proactive, ex ante changes where the ombudsman's future position is pre-empted, or reactive, ex post changes which arise in response to a particular decision. Some studies have

\footnotetext{
${ }^{3}$ Many of these challenges are shared with literature seeking to explore administrative responses to judicial review. See Sunkin (2004).
} 
focused solely on the approach of the ombudsman, for example, looking at whether decisions are norm-producing or whether systemic investigations have been used more frequently. ${ }^{4}$

Methodologically, there is broad consensus in the literature about the challenge of quantifying the effects of the ombudsman, especially outwith individual cases. Even within the individual case, given that a core goal of the ombudsman is to improve the fairness of administration, and that this concept is both nebulous and difficult to measure, empirical enquiry is a complex endeavor. As already discussed above, the role plurality and ambiguity of the ombudsman is an added challenge in operationalizing research. Timing is another important methodological challenge, with most studies measuring responses of government to the ombudsman at a single point in time, rather than longitudinally. The sustainability of change and learning is rarely addressed (Steyvers and Reynart 2009). Even where clear changes in administrative practice can be identified through research, scholars are likely to be left with difficulties establishing causality, particularly given the increasingly complex and multi-level nature of modern government. Overall, conclusions presented by authors often depend on the expectations of researchers or on the implicit or explicit basis on which evaluations are being made. For example, one author is impressed by the European Ombudsman's fairly lackluster compliance record because of a belief that compliance is less likely without enforcement powers (Kostadina, 2015). Finally, studies have tended to use either qualitative or quantitative methods, but in both cases have tended to rely predominantly on data reported by bureaucrats themselves. Few studies have been able to gain access to administrative records or been able to conduct sustained observation of bureaucratic responses. The expense, ethical challenges, and difficulty in securing access for such research mean that the quality of the evidence gathered in studies has tended to be of largely exploratory value.

\section{The findings of empirical studies}

Beginning with research which has produced more pessimistic or at least ambivalent findings, Hill (1972) conducted the first empirical study seeking to evaluate the effect of ombudsman schemes on public administration. He investigated the reactions of senior civil servants in New Zealand to the New Zealand Ombudsman. His findings indicate that although administrators and the ombudsman shared a congruent and mutually reinforcing set of values, most considered that the ombudsman had little impact on their work: 68 per cent said the ombudsman had no impact on administration, while 32 per cent said it had some and had made them more careful.

Gregory and Hutchesson (1975) conducted a small scale empirical enquiry as part of a broader piece of research looking at the UK's Parliamentary Commissioner for Administration (PCA). They found that the creation of the PCA in 1967 had not led to any changes in the attitudes of central government administrators and that, although changes to procedures and administrative systems had been brought about, these were peripheral. Gill (2012), meanwhile, conducted a small-sample study of the ex ante impact of the Scottish Public Services Ombudsman on the decision-making of local authority housing departments. He found that administrators showed little detailed awareness of the ombudsman's rulings and that commitment to learning from the work of the ombudsman was variable. ${ }^{5}$ Recognising the limited nature of the study and that its findings were less positive than a number of others, Gill

\footnotetext{
${ }^{4}$ The summary of findings below only considers studies which have examined government responses to the ombudsman.

${ }^{5}$ This study was carried out before the reforms to the SPSO discussed earlier in this chapter.
} 
nonetheless suggested a need for greater caution in assessing the claims made about the impact of ombudsman schemes, because many of the barriers that affect the ability of judicial review to control administrative action were also likely to affect ombudsman schemes. Steyvers and Reynart's (2009) study of the impact of the Ghent Ombudsman, sought to assess the ombudsman's influence on government through reputational analysis, whereby citizens were asked to assess the extent to which government was responsive to the ombudsman. They found that the vast majority of citizens did not feel able to provide a view on this. While this highlights a clear limitation in using reputational analysis to investigate how government responds to the ombudsman, the finding is nonetheless interesting in highlighting the fact that citizens seem to know relatively little about the ombudsman's learning role.

Turning to studies that have resulted in more upbeat findings, Friedmann (1976) researched the impact of the Alberta Ombudsman on public services and found that, while the ombudsman was rarely in the minds of administrators as they conducted their day-to-day work, attitudes to the ombudsman scheme were very positive. Overall, Friedmann concluded that given the positive attitudes of officials toward the ombudsman, it was likely to have a considerable ability to influence public administration. Hertogh's (2001) research explored the impact of the administrative courts and the ombudsman in the Netherlands. His findings in relation to the ombudsman suggested that its cooperative approach helped to reduce the barriers to administrators making changes to policies and procedures. His concluding hypothesis was that the ombudsman's collaborative style of control was likely to reduce the policy tension which interfered with the ability of ombudsman decisions to be implemented. Interestingly, Pajuoja (2009) - in a study looking at the impact of the Finish Ombudsman - also found a very high level of influence, but in that case it was ascribed to the ombudsman's strong powers of coercion, which included criminal prosecution. In a sign that ombudsman schemes themselves are becoming more interested in their impact, two studies have now been commissioned by ombudsman schemes. The first, commissioned by the UK's Parliamentary and Health Services Ombudsman, examined the impact of 21 decisions which had led to adverse findings and recommendations (IFF 2010). This study concluded that individual recommendations did lead to change, although the study noted that the timeliness of investigations, some lack of clarity in recommendations, and the absence of a more cooperative approach, militated against impact in some cases. The second commissioned study, conducted on behalf of the Toronto Ombudsman, reported similarly positive findings (Steimatycki et al 2015). This study found that the ombudsman had had an 'overwhelming positive impact' on municipal administration. A particular area where administrators reported that the ombudsman had led to improvements was in terms of the way administrators communicated with members of the public and in the treatment of vulnerable citizens.

Three further recent studies have been conducted in a European context. Kostadina (2015) researched the influence of the European Ombudsman on the European Commission. She found that in the majority of cases, the ombudsman's recommendations were accepted and that the Commission was willing to learn from the ombudsman. While Kostadina's findings are clearly positive, it is notable that the rate of compliance of the European Ombudsman's recommendations is poor compared with that achieved by UK public service ombudsman schemes. Hossu and Karp (2013) studied the administrative perceptions of the Romanian Ombudsman, finding generally positive views of the ombudsman and its influence.

Administrators here reported that the ombudsman had 'very much' influenced their future activity even though they found it difficult to highlight specific changes arising from cases. 
Finally, Von Acker and his colleagues (2015) conducted a comparative study of the role of ombudsman schemes and audit bodies in generating and sustaining administrative innovation in a number of European countries, including the UK. This study's overall conclusion was that the recommendations of ombudsman schemes were effective in driving sustainable innovations in organisations.

\section{Assessing the empirical literature}

As the above summary has shown, our current empirical knowledge of government responses to the ombudsman is limited. Existing studies provide some support for those who emphasise the ombudsman's theoretical assets in helping government to learn. Most studies seem to show that when asked about the work of particular ombudsman schemes, government officials respond positively. There certainly does not appear to be much evidence of widespread disregard or rejection of the ombudsman's work. Where studies have reached more pessimistic findings, a lack of influence on the part of the ombudsman seems to be ascribed either to low awareness of the ombudsman's work or a sense that it is somewhat peripheral to routine administration. While these studies make helpful individual contributions, in aggregate they are a significant way off providing a robust evidence base and they do not allow for strong conclusions to be drawn about the empirical reality of whether government learns from the ombudsman.

\section{CONCLUSION}

Assessing the ombudsman's role in helping government to learn is not straightforward. The role itself is a contested one and the extent to which it should be pursued remains a matter for debate. There are also theoretical questions over the suitability of the ombudsman in helping government learn: the institution has some undoubted assets, but also a number of potential liabilities. These questions are exacerbated once one starts to consider these issues on a global basis. The huge variety in approaches to the ombudsman's role mean that generalization about the ombudsman's ability to engender learning in government is inherently problematic. The examples of the Scottish Public Services Ombudsman and the Ontario Ombudsman demonstrate the quite different approaches that may be adopted, even where learning is a shared ambition of both institutions.

While the small number of empirical studies concerned with examining how government responds to the ombudsman make a helpful contribution to a literature that is largely normative and descriptive in nature, these studies often raise as many questions as they answer. The significant conceptual and methodological challenges inherent in conducting empirical work mean that the findings of studies must be treated with a certain amount of caution. There is not currently a significant evidence base to draw on and, given the challenges involved in conducting such empirical studies, it is not surprising that relatively few have been carried out. The current position remains one of significant empirical ignorance.

It is also not clear - in relation to both the theoretical and empirical ombudsman literature - that sufficient notice has been taken of work carried out in the fields of public administration and organisational science, which problematizes the possibility of governmental learning. The significant barriers to learning and change in government, and the difficulty of principals exercising control over bureaucratic agents, suggests that even where bureaucrats have positive 
attitudes to the ombudsman, meaningful change is likely to be difficult to achieve. These issues tend to be either ignored or significantly underestimated in existing literature.

How can the current situation be remedied and how can we improve our understanding of the ombudsman's learning role? This chapter ends with two suggestions. Firstly, ombudsman schemes should collect and publish better data in relation to the learning that their work engenders. In the same way that policies are routinely evaluated, ombudsman schemes should seek to evaluate on an ongoing basis the effects of their interventions, whether these relate to investigations, issuing guidance, providing training, or any other activity which aims at prompting a learning response from government. There is a role here not only for individual ombudsman schemes but for ombudsman membership bodies, so that data begins to be published in ways that allow for some comparison across jurisdictions. This will also require cooperation from government, which would need to be more open and transparent in the data it makes available. $^{6}$

Secondly, primary academic research can play a role in helping to build our empirical knowledge. Particular areas where further research might be helpful include cross-jurisdictional studies and comparative work examining different ombudsman approaches to the learning role. It would, for example, be fascinating to compare the SPSO and the OO approaches discussed earlier in this chapter. Studies should also aim, insofar as it is possible, to draw on a fuller range of methodologies, using both qualitative and quantitative approaches, wherever possible seeking not only to study what government and ombudsman actors say they do but also gathering other triangulating data. Finally, studies should seek not only to measure whether learning takes place, but should seek to adopt theory building approaches which help explain when and how learning is achieved. This approach has been adopted by some of the leading work in the field to date, but has yet to be followed up. ${ }^{7}$ It is important that future work should develop existing theorybuilding work and explicitly connect with established theoretical frameworks concerned with learning and change in government.

\section{REFERENCES}

Abrahams, A. 2012. Making Sense of the Muddle: the Ombudsman and Administrative Justice. Journal of Social Welfare and Family Law, Vol. 34, p. 91.

Adler, M (ed.). Administrative Justice in Context. Oxford: Hart.

Adler, M. 2003. A Socio-Legal Approach to Administrative Justice. Law and Policy, Vol. 25, p. 323.

Alden, S. 2015. Discretion on the Frontline: The Street Level Bureaucrat in English Statutory Homelessness Services. Social Policy and Society, Vol. 14, p. 63.

Argyris, C., and Schön, D.A. Organizational Learning: A Theory for Action Perspective. Reading, Mass: Addison-Wesley.

Aucoin, P., and Heintzman,, R. 2000. The Dialectics of Accountability for Performance in Public Management Reform. International Review of Administrative Sciences, Vol. 66, p.45.

\footnotetext{
${ }^{6}$ The paucity of data available to administrative justice researchers has been a significant concern of the UK Administrative Justice Institute, www.ukaji.org.uk

${ }^{7}$ Hertogh's (2001) work is an example where policy implementation frameworks have been used to good effect to study responses to the ombudsman.
} 
Beck Jorgensen, T., and Vrangbaek, K. 2011. Value Dynamics: Towards a Framework for Analyzing Public Value Changes. International Journal of Public Administration, Vol. 34, p. 486.

Bondy, V., Doyle, M., Hirst, C. 2014. The Use of Informal Resolution by Ombuds in the UK and Ireland. London: Nuffield Foundation.

Bovens, M., Schillemans, T., and Hart,P. 2008. Does Public Accountability Work? An

Assessment Tool. Public Administration, Vol. 86, p.225.

Buck, T., Kirkham, R., and Thompson, B. 2011. The Ombudsman Enterprise and Administrative Justice. Surrey: Ashgate.

Cabinet Office. 2000. Review of the Public Services Ombudsmen in England. London: Cabinet Office.

Common, R. 2004. Organisational Learning in a Political Environment. Policy Studies, Vol. 25, p. 37.

Compton, E. 1970. The Administrative Performance of Government. Public Administration, Vol. 48, p. 3.

Diamandorous, N. 2009. The Impact of the European Ombudsman: What has Changed in the EU Administration since 1995?. The Impact of Ombudsmen, R. Passemiers, H. Reynaert and K.

Steyvers (eds.), Ghent: Vanden Broele Publishers.

Dube, Dube. 2016. Ombudsman Strategies for Getting to Yes and Beyond. Toronto: Ontario Ombudsman.

Dunsire, A. 1992. Modes of Governance. Modem Governance, J Kooiman (ed),London: Sage. Farrand, J. 1999. Ombudsman or Tribunal? Administrative Justice in the 21st Century, M. Harris and M. Partington (eds.), Oxford: Hart Publishing.

Friedmann, K. A. 1976. Controlling Bureaucracy: Attitudes in the Alberta Public Service Towards the Ombudsman. Canadian Public Administration, Vol. 19, p. 51.

Galligan, D.J. 1996. Due Process and Fair Procedures: A Study of Administrative Procedures. Oxford: Clarendon Press.

Giddings, P. 2008. The Parliamentary Ombudsman: Classic Watchdog. Parliament's

Watchdogs: At the Crossroads , O. Gay, and B. Winetrobe (eds.), London: UCL Constitution Unit.

Gill, C. 2012. The Impact of the Scottish Public Services Ombudsman on Administrative Decision-Making in Local Authority Housing Departments. Journal of Social Welfare and Family Law, Vol. 34, p. 197.

Gill, C. 2014. The Evolving Role of the Ombudsman: a Conceptual and Constitutional Analysis of the 'Scottish Solution' to Administrative Justice. Public Law, p. 662.

Gill, C., Williams, J., Brennan, C., O’Brien, N. 2013. The Future of Ombudsman Schemes. Birmingham: Legal Ombudsman.

Gilson, C., Dunleavy, P., and Tinkler, J. 2009. Organizational Learning in Government Sector Organizations: Literature Review (London: National Audit Office/ LSE Public Policy Group.

Gormley, W.T., and Balla, S.J. 2004. Bureaucracy and Democracy: Accountability and Performance New York: CQ Press.

Gregory, R., and Drewry, G. 1991. Barlow Clowes and the Ombudsman - Part 1'. Public Law, p. 192.

Gregory, R., and Hutchesson, P. 1975. The Parliamentary Ombudsman: A Study in the Control of Administrative Action. London: Allen and Unwin.

Harlow, C. 1978. Ombudsmen in Search of a Role. Modern Law Review, Vol. 41, p. 446. 
Harlow, C., and Rawlings, R. 2009) Law and Administration ( $3^{\text {rd }}$ edn). Cambridge: Cambridge University Press.

Heede, K. 2000. The European Ombudsman: Redress and Control at Union Level. The Hague: Kluwer Law International .

Hertogh, M. 2001.Coercion, Cooperation and Control: Understanding the Policy Impact of Administrative Courts and the Ombudsman in the Netherlands. Law and Policy, Vol. 23, p. 47.

Hertogh, M., and Halliday, S. 2004. Judicial Review and Bureaucratic Impact. Cambridge: Cambridge University Press.

Hill, L.B. 1972. Affect and Interaction in an Ambiguous Authority Relationship: New Zealand's Bureaucrats and the Ombudsman. Administration and Society, Vol. 4, p. 35.

Hood, C. 1991. A Public Management for All Season. Public Administration, Vol. 69, p.3.

Hood, C. 1995. Control over Bureaucracy: Cultural Theory and Institutional Variety. Journal of Public Policy, Vol. 15, p. 207;

Hood, C., and Dixon, R. 2015. A Government that Worked Better and Cost Less? Evaluating

Three Decades of Reform and Change in UK Central Government. Oxford: Oxford University

Press.

Hood, C., Scott, C., James, O., Jones, G., Travers, T. 2000. Regulation Inside Government. Oxford: Oxford University Press.

Hossu, L.A., and Karp, R. 2013. The Multifaceted Image of the Romanian Ombudsman.

Transylvanian Review of Administrative Science, Vol. 40, p. 71.

IFF Research. 2010. PHSO Impact Study. London: IFF. .

Jones, G. 2009. Conducting Administrative, Oversight and Ombudsman Investigations. Toronto: Canada Law Books.

Jos , P.H., and Tompkins, M.E., 2004. The Accountability Paradox in an Age of Reinvention. Administration and Society, Vol. 36, p. 255.

King, J. 2012. Judging Social Rights. Cambridge: Cambridge University Press.

Kirkham, R. 2005. A Complainant's View of the Local Government Ombudsman. Journal of

Social Welfare and Family Law, Vol. 27, p. 383.

Kirkham, R. 2006. Challenging the Authority of the Ombudsman. The Parliamentary

Ombudsman's Special Report on Wartime Detainees. Modern Law Review, Vol. 69, p. 792.

Kirkham, R. 2007. Withstanding the Test of Time. London: The Stationery Office.

Kirkham, R., Thompson, B., and Buck, T. 2008. When Putting Things Right Goes Wrong:

Enforcing the Recommendations of the Ombudsman. Public Law, p. 510.

Kostadina, P. 2015. Improving the Transparency and Accountability of EU Institutions: The

Impact of the Office of the European Ombudsman. Journal of Common Market Studies, Vol. 53, p. 1077.

Leeuw, F.L., and Sonnichsen, R.C. 1994. Evaluation and Organisational Learning: International Perspectives. Can Governments Learn? Comparative Perspectives on Evaluation and

Organisational Learning, F.L. Leeuw, and R.C. Sonnichsen (eds.), Abingdon: Transaction

Publishers.

Lewis, N., Birkinshaw, P. 1993. When Citizens Complain: Reforming Justice and

Administration. London: Open University Press.

LGO. 1993.Axioms of Good Administration. Coventry: LGO.

Lipsky, D. 1980. Street Level Bureaucracy: Dilemmas of the Individual in Public Services. New York: Russel Sage Foundation. 
Maggette, P. 2003. Between Parliamentary Control and the Rule of Law: the Political Role of the Ombudsman in the European Union. Journal of European Public Policy, Vol. 10, p. 677.

Marin, A. 2009. Leveraging Moral Suasion through SORT Investigations. Speech to the International Ombudsman Institute Conference, Stockholm 2009.

Mashaw, J. Bureaucratic Justice. New Haven: Yale University Press.

O'Brien, N. 2015. What Future for the Ombudsman? The Political Quarterly, Vol. 86, p. 72.

O'Reilly, E. 2009. Watching the Watchdogs. The Impact of Ombudsmen, R. Passemiers, H.

Reynaert and K. Steyvers (eds.), Ghent: Vanden Broele Publishers.

Pajuoja, J. 2009. The Impact of the Parliamentary Ombudsman Institution in Finland. The Impact

of Ombudsmen, R. Passemiers, H. Reynaert and K. Steyvers (eds.), Ghent: Vanden Broele

Publishers.

PHSO. 2009. Principles of Good Administration. London: PHSO.

Pollitt, C. 2009. Bureaucracies Remember, Post-bureaucratic Organizations Forget? Public Administration, Vol. 87, p. 198.

Pressman, J.L., and Wildavsky, A. Implementation: How Great Expectations in Washington are Dashed in Oakland; or, Why it's Amazing That Federal Programs Work at All. California:

University of California Press.

Reif, L. 2004. The Ombudsman, Good Governance and International Human Rights. New York: Springer Science and Business Media .

Remac, M. 2013. Standards of Ombudsman Assessment: A New Normative Concept?. Utrecht

Law Review, Vol. 9, p. 62.

Rothstein, B. 1998. Just Institutions Matter: The Moral and Political Logic of the Universal

Welfare State. Cambridge: Cambridge University Press.

Scottish Government. 2008. Fit for Purpose Complaint System Action Group, Report to

Ministers. Edinburgh: Scottish Government.

Seneviratne, M. Ombudsmen: Public Services and Administrative Justice. London: Butterworths. Snell, R. 2000. Towards an Understanding of a Constitutional Misfit: Four Snapshots of the Ombudsman Enigma. Sunrise or Sunset? Administrative Law in the New Millennium, C. Finn (ed.), Sydney: Australian Institute of Administrative Law.

SPSO. 2016. Annual Report 2015 - 2016. Edinburgh: SPSO.

Steimatycki, M., Noack, A., Kane, J., Valade, M., Crean, F., Cook, G. 2015. The Impact of

Ombudsman Investigations on Public Administration: A Case Study and Evaluation Guide.

Toronto: Toronto Ombudsman/ International Ombudsman Institute.

Steyvers, K., and Reynart, H. Assessing Ombudsman Impact: Exploring the Ghent Case. The

Impact of Ombudsmen, R. Passemiers, H. Reynaert and K. Steyvers (eds.), Ghent: Vanden

Broele Publishers.

Stuhmcke, A. 2010. Each for Themselves or One for All? The Changing Emphasis of the

Commonwealth Ombudsman. Federal Law Review, Vol. 48, p.143.

Stuhmcke, A. 2012. The Evolution of the Classical Ombudsman: a View from the Antipodes.

International Journal of Public Law and Policy, Vol. 2, p. 83.

Sunkin, M. 2004. Conceptual Issues in Researching The Impact of Judicial Review on

Government Bureaucracies. Judicial Review and Bureaucratic Impact, M. Hertogh, and S.

Halliday (eds), Cambridge: Cambridge University Press.

Thomas, R. 2015. Administrative Justice, Better Decisions and Organizational Learning. Public

Law, p.111. 
Thompson, B. 2006. The Scottish Public Services Ombudsman: Revolution or Evolution? Public Law in Scotland, A. McHarg, and T. Mullen (eds.) Edinburgh: Avizandum.

Van de Pol, U. 2009. The Added Value of a Local Ombudsman The Impact of Ombudsmen, R. Passemiers, H. Reynaert and K. Steyvers (eds.), Ghent: Vanden Broele Publishers.

Von Acker, W., Bouckaert, G., Frees, W., Nemec, J., Lawson, C., Matei, A., Savulescu, C., Monthubert, E., Nederhand, J., Fleming, S. 2015. Mapping and Analysing the Recommendations of Ombudsmen, Audit Offices and Emerging Accountability Mechanisms. Research Report No. 3 of the LIPSE Project 2015. 
Tables

Table 1

\begin{tabular}{|l|l|}
\hline Potential Assets & Potential Liabilities \\
\hline Inquisitorial powers & Contested role \\
\hline Own initiative powers & Constitutional uncertainty \\
\hline Power to recommend & Informal resolution/ settlement approaches \\
\hline Flexible and broad standards & A lack of principled approach \\
\hline Special reports and guidance & Lack of formal enforcement \\
\hline Cooperative approach & Ombudsman 'capture' \\
\hline Use of publicity & Unintended consequences \\
\hline Tonic effect & Not all have own initiative powers \\
\hline Suited to polycentric problems & Complaints are episodic \\
\hline
\end{tabular}

Table 2

\begin{tabular}{|l|l|l|}
\hline & SPSO & OO \\
\hline Control tools & Quasi-regulatory & Systemic investigation \\
\hline Stance to government & Collaborative, low conflict & Adversarial, high conflict \\
\hline Source of legitimacy & Relationship with bureaucrats & Relationship with citizens \\
\hline Media style & Low media profile & High media profile \\
\hline Main focus & Complaint handling processes & Substantive policy \\
\hline Training & Public servants & Other ombudsman schemes \\
\hline
\end{tabular}

